\title{
Określenia nieostre w przepisach dotyczących przedmiotu opodatkowania podatkiem dochodowym od osób fizycznych (wprowadzenie do problematyki)
}

\begin{abstract}
Vague terms in the Polish personal income tax regulations: The author discusses the selected problems related to the vague terms and general clauses in the personal income tax laws in Poland, with particular attention given to the term of subject of taxation. The author overviews the requirements for the use of vague terms and explains the rationale behind it, which is, inter alia, the need for greater flexibility of interpretation. The author claims that the legislators do not always properly use vague terms in the tax law, and their complexity and overload can lead to dilemmas. Some recommendations on the proper use of such terms in personal income tax legislation are given.
\end{abstract}

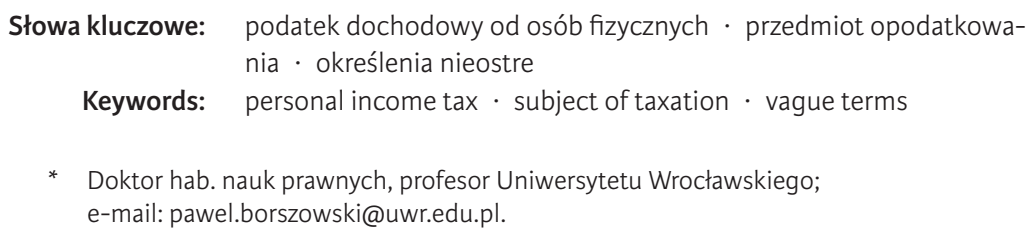

\section{Wstęp}

Analiza zastosowania określeń nieostrych, a także klauzul generalnych w prawie podatkowym zyskuje coraz bardziej na aktualności ${ }^{1}$. Jest to zagadnienie istotne dla prawa podatkowego. Niewątpliwie prostszym rozwiązaniem legislacyjnym jest wprowadzenie środków techniki prawodawczej zapewniających

1 Wskazać warto opracowania monograficzne, tj. A. Choduń, A. Gomułowicz, A. Skoczylas, Klauzule generalne i zwroty niedookreślone $w$ prawie podatkowym i administracyjnym. Wybrane zagadnienia teoretyczne i orzecznicze, Wolters Kluwer Polska, Warszawa 2013; P. Borszowski Określenia nieostre i klauzule generalne w prawie podatkowym, Wolters Kluwer Polska, Warszawa 2017, czy opracowanie M. Münnich, Nieostre zwroty ocenne w polskim prawie podatkowym, Wydawnictwo KUL, Lublin 2017. 
elastyczność tekstu aktu normatywnego stosownie do rozporządzenia w sprawie "Zasad techniki prawodawczej”2 $\mathrm{w}$ tych aktach normatywnych, które oparte są na cywilnoprawnej metodzie regulacji. Jednakże również w przepisach prawa podatkowego ustawodawca stosuje tego typu rozwiązania normatywne. Uzasadnienie dla ich użycia $w$ regulacjach prawa podatkowego zdaje się być wyjaśnione w literaturze przedmiotu ${ }^{3}$. Przy czym przeważająca część tych rozważań dotyczy unormowań ogólnego prawa podatkowego. Nie oznacza to, że problemy dotyczące tej sfery analizy dotyczą jedynie tych unormowań. Ustawodawca podatkowy może i korzysta $\mathrm{z}$ tych rozwiązań normatywnych również w tych ustawach podatkowych, które tworzą szczegółowe prawo podatkowe. $\mathrm{W}$ przypadku badania tej problematyki w obszarze ogólnego prawa podatkowego można posłużyć się instytucją zobowiązania podatkowego, gdzie normodawca w przepisach prawnych zastosował określenia nieostre czy też klauzule generalne. Warto przy tym podkreślić, że w niniejszym opracowaniu zastosowano termin „określenie nieostre” $w$ takim sensie, jaki zaproponowano w przywoływanym już rozporządzeniu w sprawie „Zasad techniki prawodawczej”, dla odróżnienia od klauzul generalnych (klasycznych) ${ }^{5}$. Rozpatrywanie tych środków techniki prawodawczej w odniesieniu do instytucji zobowiązania podatkowego jest możliwe ze względu na jego analizę funkcjonalną, a zatem łatwiej jest uwzględnić aspekt prawa w działaniu wraz z tworzeniem zakresu nieostrości danego wyrażenia.

Badanie określeń nieostrych w ramach szczegółowego prawa podatkowego wymaga uwzględnienia techniki podatkowej. Normodawca wykorzystuje bowiem technikę podatkową, według której konstruuje dany rodzaj podatku, gdzie wskazuje się poszczególne elementy tej techniki czy też elementy konstrukcji prawnej podatku'. Niemniej elementy te nabierają zróżnicowanego kształtu normatywnego, w zależności od danego rodzaju obciążenia podatkowego. Przykładowo zatem inaczej będzie skonstruowany przedmiot opodatkowania w podatkach majątkowych, a inaczej w podatkach dochodowych. Przekłada się to zatem nie tylko na sposób regulacji, ale także na, będący jego konsekwencją, zakres normatywny zwrotów użytych do tworzenia danego ele-

2 Chodzi o $\$ 155$ ust. 1 rozporządzenia Prezesa Rady Ministrów z 20 czerwca 2002 r. w sprawie „Zasad techniki prawodawczej”, t.j. Dz.U. 2016, poz. 283.

3 Zobacz P. Borszowski, Określenia, op. cit., s. 59 i n.

${ }^{4}$ Paragraf 155 ust. 1 tego rozporządzenia, a także M. Zieliński [w:] S. Wronkowska, M. Zieliński, Komentarz do zasad techniki prawodawczej, Wydawnictwo Sejmowe, Warszawa 2012, s. 296.

${ }^{5}$ Przy czym jak podkreśla się w literaturze, również określenia nieostre mogą być nazywane klauzulami generalnymi funkcjonalnymi, M. Zieliński [w:] S. Wronkowska, M. Zieliński, Komentarz, op. cit., s. 297.

6 Te pojęcia stosowane są zamiennie w literaturze. R. Mastalski wskazuje na elementy techniki podatkowej, idem, Prawo podatkowe, C.H. Beck, Warszawa 2016, s. 48 i n. 
mentu konstrukcji prawnej podatku. Niewątpliwie ma to znaczenie dla sposobu użycia określeń nieostrych. Wydaje się, że jest to jedno z istotnych zagadnień, które powinien uwzględnić normodawca, decydując się na skorzystanie $\mathrm{z}$ określenia nieostrego $\mathrm{w}$ regulacji będącej składową elementu konstrukcji danego podatku. Tym samym nie tylko uniknie się zarzutu przypadkowości użycia tego środka techniki prawodawczej, ale także obawy przed doprowadzeniem do zbyt dużego obszaru nieostrości danego wyrażenia.

Niniejsze opracowanie ma wymiar wprowadzenia do problematyki, stąd też uwagi tu zawarte są pewnym uogólnieniem, stanowiąc bazę do dalszego rozpatrywania w szczegółowych analizach w kolejnych opracowaniach. Dlatego też rozbudowano nieco część ogólną, natomiast rozważania dotyczące konkretnych rozwiązań w regulacjach prawa podatkowego ograniczono do wybranych przepisów prawnych. Dla zobrazowania istotnych problemów pojawiających się przy posługiwaniu się określeniami nieostrymi w ramach szczegółowego prawa podatkowego do analizy wybrano przedmiot opodatkowania w podatku dochodowym od osób fizycznych ${ }^{7}$ co najmniej z dwóch względów. Po pierwsze, z uwagi na znaczenie tej problematyki dla samego przedmiotu opodatkowania jako elementu konstrukcji prawnej podatku. Po drugie, z powodu kształtu normatywnego przedmiotu opodatkowania w podatku dochodowym od osób fizycznych. Nie tylko bowiem chodzi o rozpatrywanie dwóch składowych tego przedmiotu opodatkowania, tj. przychodów i kosztów uzyskania przychodów, przy posługiwaniu się w ramach przepisów ich dotyczących określeniami nieostrymi, ale także z uwagi na zróżnicowanie źródeł przychodów, charakterystyczne dla tego podatku.

Celem niniejszego opracowania jest dokonanie analizy sposobu korzystania $\mathrm{z}$ określeń nieostrych $\mathrm{w}$ strukturze przedmiotu opodatkowania podatkiem dochodowym od osób fizycznych. Hipoteza sprowadza się do stwierdzenia, że użycie tych rozwiązań normatywnych nie zawsze uwzględnia specyfikę konstrukcji tego przedmiotu opodatkowania, co może powodować zbyt duży stopień elastyczności, a w konsekwencji zbyt duży obszar nieostrości. W pierwszej kolejności należy zatem ustalić kryterium użycia określenia nieostrego w odniesieniu do przedmiotu opodatkowania jako elementu konstrukcji prawnej podatku.

\section{Kryterium użycia określenia nieostrego a przedmiot opodatkowania}

Podstawę rozważań na temat kryterium użycia określenia nieostrego można dostrzec już w samym rozwiązaniu zaproponowanym w rozporządzeniu w sprawie „Zasad techniki prawodawczej”, gdzie posłużono się sformułowa-

7 Ustawa z 26 lipca 1991 r. o podatku dochodowym od osób fizycznych, t.j. Dz.U. 2018, poz. 200, ze zm.; dalej: u.p.d.f. 
niem „potrzeba zapewnienia elastyczności tekstu aktu normatywnego" ${ }^{\text {. Prze- }}$ nosząc je na obszar regulacji prawa podatkowego, można skorzystać ze sformułowania „elastyczność przepisów prawa podatkowego", gdzie elastyczność odnosi się do przepisów prawnych jako pewnych składowych tekstu aktu normatywnego. Problemem dla ustawodawcy, ale też i praktyki stosowania prawa podatkowego, jest kryterium, na podstawie którego prawodawca powinien zapewniać tę elastyczność, o ile jest to możliwe. Nie można bowiem przyjąć poglądu, że wyrażenie „potrzeba zapewnienia elastyczności” prowadzi do tego, iż normodawca w obszarze danej gałęzi prawa nie ma wskazanego kryterium zastosowania określeń nieostrych. Nie ulega wątpliwości, że zwrot „potrzeba" jest już określeniem nieostrym, jednakże wymagającym jego odniesienia do konkretnej gałęzi prawa i konkretnej instytucji prawnej, a nawet regulacji, w obszarze której dojdzie do wprowadzenia określenia nieostrego. Posłużenie się kryterium potrzeby użycia środka techniki prawodawczej zapewniającego elastyczność tekstu aktu normatywnego jest jedynie pewnym punktem wyjścia, gdyż daje podstawę do poszukiwania konkretnego kryterium w obszarze danej gałęzi prawa, instytucji czy nawet regulacji. W literaturze przyjęto, że przełożenie tego sformułowania w obszar prawa podatkowego wiąże się z pewnym wymogiem jego zaostrzenia ${ }^{10}$, by nie doprowadzić do stworzenia zbyt dużego zakresu nieostrości, zwiększonego następnie przez użycie określenia nieostrego. Tym samym postulowane kryterium konieczności ${ }^{11}$ zapewnienia elastyczności przepisów prawa podatkowego należy odnieść nie tylko do ogólnego prawa podatkowego, lecz również do szczegółowego prawa podatkowego, w tym rozpatrywanego przedmiotu opodatkowania. Nie wydaje się bowiem właściwe ustalanie innego kryterium ze względu na relację między ogólnym a szczegółowym prawem podatkowym. W pewnym uproszczeniu oznacza to zatem wymóg badania umownie nazwanych trzech etapów, tj. podjęcia decyzji użycia określenia nieostrego, a następnie jego sformułowania i umieszczenia $\mathrm{w}$ przepisach dotyczących przedmiotu opodatkowania.

Rozważenie tego kryterium nie jest przypadkowe. Element przedmiotu opodatkowania został wymieniony w początkowym zakresie przepisu art. 217 Konstytucji ${ }^{12}$. Jego znaczenie dla zakreślenia obszaru opodatkowania jest niezwykle istotne. Jest to bowiem element, za pomocą którego ustawodawca podatkowy de facto decyduje o tym opodatkowaniu. Wymóg ustawowego określenia przedmiotu opodatkowania, sprowadzający się do zapewnienia właściwego

${ }^{8}$ Chodzi o $\$ 155$ ust. 1 tego rozporządzenia.

9 Zob. P. Borszowski, Określenia, op. cit., s. 37, i literatura tam przywołana.

${ }^{10}$ Ibidem, s. 64.

11 Ibidem.

12 Konstytucja Rzeczypospolitej Polskiej z 2 kwietnia 1997 r., Dz.U. nr 78, poz. 483, ze zm. 
poziomu regulacji ustawowej, tzw. głębokości regulacji ${ }^{13}$, ma istotne znaczenie dla całej konstrukcji danego podatku. A zatem zastosowanie do przedmiotu opodatkowania określeń nieostrych powinno spełniać podwyższony standard legislacji, by nie doprowadzić nie tylko do jego niewłaściwego ukształtowania, ale także zbyt dużej nieostrości. Ponadto wydaje się, że nie ma możliwości zbudowania tego elementu konstrukcji prawnej podatku bez użycia tych środków techniki legislacyjnej, co pokazuje nie tylko sam ustawodawca w regulacji przedmiotu opodatkowania podatkiem dochodowym od osób fizycznych. Jest to bowiem konsekwencja dostrzegania i właściwego ujęcia w unormowaniach prawa podatkowego relacji między obrotem gospodarczym a prawem podatkowym. Chodzi więc o wyrażenie w unormowaniu przedmiotu opodatkowania odpowiedniej relacji między obrotem gospodarczym a prawem podatkowym (opodatkowaniem). Wydaje się, że istotne znaczenie powinno tu mieć kryterium konieczności.

Stąd też pojawia się pytanie o zakres kryterium konieczności. Inaczej mówiąc, czy ma ono dotyczyć wszystkich trzech, wskazanych już, umownie nazwanych etapów tworzenia określenia nieostrego w przepisach dotyczących przedmiotu opodatkowania? Czy przypadkiem nie należy tego kryterium zastosować jedynie w ramach decydowania o wykorzystaniu tego środka techniki prawodawczej, by następnie posługiwać się już kryterium potrzeby, co bardziej odpowiadałoby istocie tego rozwiązania normatywnego. A może należałoby rozważać zastosowanie tego kryterium dopiero po podjęciu decyzji, która opierałaby się na pewnej swobodzie?

Odnosząc się do trzech potencjalnych sposobów zastosowania kryterium konieczności użycia określenia nieostrego $\mathrm{w}$ ramach przedmiotu opodatkowania, należałoby zastosować pewną kolejność, a zatem uwzględnić najpierw etap wyznaczony jako pojedynczy, a następnie do ich zbiorczego ujęcia. Przy czym przez zbiorcze ujęcie należy rozumieć wskazane trzy etapy, czyli podjęcia decyzji o zastosowaniu tego środka techniki prawodawczej, następnie jego sformułowanie i wreszcie umieszczenie w przepisach wyrażających przedmiot opodatkowania.

Warto zatem opowiedzieć się w kwestii jego wykorzystania wyłącznie na etapie podjęcia decyzji co do posłużenia się określeniem nieostrym w przepisach dotyczących przedmiotu opodatkowania. Zawęża to pole manewru normodawcy, ale spełnia jednocześnie wymóg administracyjnoprawnej metody regulacji, unikając zbyt dowolnego podejmowania decyzji o zastosowaniu określenia nieostrego, a tym samym otwarcia danego zakresu przedmiotu opodatkowania. Jeżeli jednak na dalszym etapie korzystania z tych środków

${ }_{13}$ R. Mastalski, E. Fojcik-Mastalska, Zasada zupetności ustawowej w prawie podatkowym [w:] Konstytucja: ustrój, system finansowy państwa. Księga pamiątkowa ku czci prof. Natalii Gajl, red. T. Dębowska-Romanowska, A. Jankiewicz, Warszawa 1999, s. 390. 
techniki prawodawczej ustawodawca posłuży się kryterium potrzeby, może to doprowadzić do niewłaściwego ukształtowania tego elementu konstrukcji prawnej podatku, a także do zaburzenia relacji między przedmiotem opodatkowania a elementem zwolnień podatkowych, szczególnie tych, które są ukształtowane jako zwolnienia przedmiotowe. Można zatem uznać, że także dla tych dalszych etapów powinno mieć zastosowanie kryterium konieczności użycia określenia nieostrego. Wydaje się, że podobne uwagi można poczynić, gdy rozważeniu podlegałoby zastosowanie kryterium potrzeby przy samym podjęciu decyzji o wykorzystaniu określenia nieostrego, a z kolei na dalszych etapach - kryterium konieczności. Zbytnie bowiem otwarcie regulacji przedmiotu opodatkowania powodowałoby obawy o zachowanie wskazanej relacji temporalnej między obrotem gospodarczym a prawem podatkowym, a następnie trudności w ukształtowaniu danego rodzaju obciążenia podatkowego $\mathrm{w}$ całym systemie prawa podatkowego. $\mathrm{W}$ takim wypadku $\mathrm{z}$ kolei posłużenie się kryterium konieczności dopiero na dalszych etapach nie zapewniłoby utrzymania podwyższonego standardu regulacji, gdy chodzi o użycie określeń nieostrych w ramach przepisów dotyczących przedmiotu opodatkowania. Należy zatem uznać, że kryterium konieczności powinno mieć zastosowanie do wszystkich wskazanych etapów wykorzystania tych rozwiązań normatywnych $\mathrm{w}$ ramach regulacji przedmiotu opodatkowania.

\section{Kryterium konieczności użycia określenia nieostrego w ramach przedmiotu opodatkowania podatkiem dochodowym od osób fizycznych}

Kształt regulacji przedmiotu opodatkowania w podatku dochodowym od osób fizycznych pozwala wskazać nie tyle sam dochód (zgodnie z art. 9 ust. 1 u.p.d.f.), co pewne czynności prowadzące do jego uzyskania ${ }^{14}$. Analiza przedmiotu opodatkowania prowadzi zatem w pierwszej kolejności do normatywnej definicji dochodu. Przy czym, jak podkreśla się w literaturze, dla ukształtowania zakresu przedmiotowego znaczenie mają także regulacje zwolnień podatkowych ${ }^{15}$. Z uwagi na przyjętą koncepcję artykułu będącego wprowadzeniem do problematyki, rozważania zostaną poświęcone użyciu określeń nieostrych w przepisach dotyczących przedmiotu opodatkowania wyrażonego jako osiąganie dochodu, bez analizy zwolnień podatkowych. Można więc zbadać posłużenie się określeniami nieostrymi w niejako dwóch składowych przedmiotu opodatkowania w tym ujęciu, tj. przychodów i kosztów ich uzyskania jako konsekwencji normatywnej definicji dochodu (stosownie do art. 9 ust. 2 u.p.d.f.).

\footnotetext{
14 R. Mastalski, Prawo, op. cit., s. 423-424.

${ }^{15}$ Ibidem, s. 424.
} 
W pierwszej kolejności należałoby więc rozpatrzyć zastosowanie kryterium konieczności wraz z wymienionymi już etapami użycia tych środków techniki prawodawczej w odniesieniu do dwóch składowych przedmiotu opodatkowania w sensie całości, a zatem przykładowo bez analizy tego w konstrukcji kosztów uzyskania przychodów. Inaczej mówiąc, warto najpierw rozważyć wykorzystanie tych rozwiązań normatywnych, biorąc pod uwagę samą relację przychodów do kosztów uzyskania przychodów jako składowych przedmiotu opodatkowania. Można uznać, że znaczenie będzie tu odgrywać kryterium konieczności przede wszystkim w pierwszym $\mathrm{z}$ etapów, tj. samego podjęcia decyzji o zastosowaniu określenia nieostrego w ramach przychodów i kosztów uzyskania przychodów. Sformułowanie bowiem i ich umiejscowienie będzie miało znaczenie przy badaniu ich wykorzystania w konstrukcji przychodów i kosztów ich uzyskania.

Jeżeli chodzi o podjęcie decyzji o zastosowaniu przez ustawodawcę określeń nieostrych $\mathrm{w}$ unormowaniu przedmiotu opodatkowania $\mathrm{w}$ podatku dochodowym od osób fizycznych, wydaje się, że należy zwrócić uwagę na dwa momenty. Pierwszy z nich będzie konsekwencją poszukiwania granic opodatkowania dochodów osób fizycznych, a więc niejako będzie skutkiem powiązań między zakresem opodatkowania dochodów osób fizycznych a obrotem gospodarczym w odniesieniu do aktywności osób fizycznych. Z kolei drugi z momentów prowadzi do odpowiedzi na kluczową w tym miejscu kwestię, tj. konieczności użycia określeń nieostrych w obu wskazanych składowych przedmiotu opodatkowania. Chodzi więc o odpowiedź na pytanie, czy rozpatrywane kryterium prowadzi do przyjęcia poglądu o konieczności użycia ${ }^{16}$ określeń nieostrych w konstrukcji przychodów i kosztów ich uzyskania. Należy uznać, że nie tylko konsekwencje zastosowania kryterium konieczności, ale także jego odniesienie do relacji między przychodami i kosztami uzyskania przychodów pozwalają przyjąć pogląd o korzystaniu z tych rozwiązań normatywnych w regulacji obu składowych przedmiotu opodatkowania ${ }^{17}$. Gdyby zatem

16 Celowo nie posługuję się terminem jednoczesnego użycia przychodów i kosztów, gdyż należałoby doprecyzować, czy chodzi wyłącznie o kontekst temporalny, zakresowy, czy jeszcze inny. $Z$ uwagi na pewne wprowadzenie do dyskusji szczegółowe rozważania wykraczają poza niniejszy artykuł.

${ }_{17}$ Potwierdzeniem tego poglądu są przepisy określające zarówno przychody, jak i koszty ich uzyskania. W pierwszym przypadku wypada przywołać katalog źródeł przychodów z art. 10 u.p.d.f., gdzie wskazuje się na inne źródła przychodów, unormowania użyte przy precyzowaniu poszczególnych źródeł przychodów, jak choćby zwrot wszelkiego rodzaju wypłaty pieniężne $\mathrm{w}$ art. 12 ust. 1 u.p.d.f. czy sformułowanie użyte $\mathrm{w}$ ramach ogólnej definicji przychodów, gdzie wskazuje się na inne nieodpłatne świadczenia (art. 11 ust. 1 u.p.d.f.). Przy regulacji kosztów uzyskania przychodów przykładem jest już sama ich definicja $z$ art. 22 ust. 1 u.p.d.f., gdzie określenia nieostre użyto do wyrażenia celowego sposobu działania podmiotu. 
ustawodawca zdecydował posłużyć się określeniami nieostrymi tylko w jednym $\mathrm{z}$ tych składowych, mogłoby to spowodować negatywne konsekwencje dla całego przedmiotu opodatkowania, jak choćby rozszerzenie zakresu przychodów w stosunku do kosztów ich uzyskania ${ }^{18}$. Należy więc uznać, że kryterium konieczności prowadzi do skorzystania $\mathrm{z}$ określeń nieostrych $\mathrm{w}$ obu składowych przedmiotu opodatkowania w podatku dochodowym od osób fizycznych.

Zastosowanie kryterium konieczności przy kolejnych etapach użycia określeń nieostrych, a więc ich formułowania i umieszczenia, wymaga odrębnej analizy w ramach przychodów, jak również kosztów uzyskania przychodów. Biorąc pod uwagę dostrzegalne trzy zakresy unormowań dotyczących przychodów, tj. katalog źródeł przychodów, ich ogólną definicję, a także szczegółową regulację danego źródła przychodu, trudno rozstrzygnąć o kolejności skorzystania przez normodawcę z tych środków techniki prawodawczej dla wymienionych zakresów. Nie można także przesądzać o stopniu elastyczności, jako konsekwencji użycia danego określenia nieostrego, a tym samym obszarze nieostrości. Można formułować pewną dyrektywę użycia określeń nieostrych, biorąc pod uwagę relację zakresową między wskazanymi przepisami dotyczącymi przychodów w podatku dochodowym od osób fizycznych. W związku z tym, skoro unormowania dotyczące katalogu źródeł przychodów są nie tylko wymienione w ustawie o podatku dochodowym od osób fizycznych w pierwszej kolejności, ale także spełniają taką funkcję, należałoby postulować formułowanie i umieszczenie tych określeń nieostrych $\mathrm{z}$ dużą ostrożnością. O ile zatem samo ich umieszczenie w końcowym fragmencie regulacji art. 10 ust. 1 u.p.d.f. jest rozwiązaniem uzasadnionym, o tyle już jego kształt pozostawia wątpliwości, gdy chodzi o zbytnie otwarcie tego zakresu źródeł przychodów. Użycie wyrażenia „inne źródła” prowadzi do zbyt dużego stopnia elastyczności, a przez to obszaru nieostrości, który nie został ograniczony w przepisie art. 20 u.p.d.f., będącym jedynie częściowym jego doprecyzowaniem. Ustawodawca bowiem posługuje się przykładowym wyliczeniem innych źródeł. Lepszym rozwiązaniem byłoby bowiem wskazanie pewnych „cech jakościowych”, które pozwoliłyby zidentyfikować inne źródła przychodów. Do rozważenia byłoby umieszczenia takiego przepisu w art. 20 u.p.d.f., przed przykładowym wyliczeniem, czy też w ramach art. 10 u.p.d.f. po wyliczeniu źródeł przychodów. Niewątpliwie takie rozwiązanie normatywne bardziej spełniałoby analizowane kryterium korzystania z określeń nieostrych.

Jeżeli chodzi z kolei o formułowanie pewnej dyrektywy użycia tych środków legislacyjnych w pozostałych regulacjach wydaje się, że w ogólnej definicji przychodów ustawodawca nie powinien posługiwać się określeniami nieostry-

${ }_{18}$ Inny problem dotyczy możliwości w ogóle tworzenia przepisów o kosztach uzyskania przychodów bez wykorzystania określeń nieostrych. 
mi dla ustalania ich zakresu, a jedynie w pewnym odniesieniu do niektórych cząstkowych unormowań. Taką rolę spełnia przepis art. 11 u.p.d.f. w obecnym kształcie, gdzie posłużono się terminem „innych nieodpłatnych świadczeń”, jednakże w końcowym fragmencie tej definicji. Ponadto wykorzystano także wyrażenie „w szczególności”, jednakże jedynie dla pewnego uelastycznienia sposobu ustalania wartości pieniężnej świadczeń w naturze.

W przypadku użycia określeń nieostrych w pozostałych unormowaniach, przez które normodawca precyzuje poszczególne źródła przychodów, należy przyjąć dyrektywę wyjątkowego posługiwania się tego typu środkami techniki prawodawczej. Ustawodawca podatkowy powinien unikać tych rozwiązań normatywnych w początkowej części przepisów pełniących de facto rolę definicji danego źródła. Użycie określeń nieostrych w początkowym fragmencie regulacji, jak ma to miejsce $w$ art. 12 czy 18 u.p.d.f., jest uzasadnione specyfiką danego źródła przychodów. Dlatego też należy uznać, że obecny kształt przepisów ustawy o podatku dochodowym od osób fizycznych spełnia tę dyrektywę.

Jeżeli chodzi o posłużenie się określeniami nieostrymi w konstrukcji kosztów uzyskania przychodów, to, biorąc pod uwagę dwa dostrzegalne zakresy regulacji ${ }^{19}$, można także wskazać pewną dyrektywę. Niewątpliwie trudno byłoby stworzyć taką definicję bez skorzystania z określeń nieostrych. Rozwiązanie, jakie przyjął normodawca, czyli szczegółowe wskazanie wydatków nieuznawanych za koszty, a oparcie definicji na tych środkach techniki prawodawczej jest prawidłowe, gdy ocenić użycie rozwiązań zapewniających elastyczność przepisów prawa podatkowego. Oddzielnym bowiem zagadnieniem, pozostającym poza ramami niniejszego opracowania, jest stopień szczegółowości regulacji wydatków nieuznawanych za koszty uzyskania przychodów i relacje zakresowe między tymi wydatkami.

Jeżeli natomiast ocenie poddać sposób użycia określeń nieostrych w przepisie art. 22 ust. 1 u.p.d.f., wydaje się, że normodawca zastosował zbyt duży stopień elastyczności, co w konsekwencji prowadzi do zbyt dużego obszaru nieostrości. Kwalifikacja zachowań podmiotu w ramach trzech wskazanych celów ${ }^{20}$ może bowiem wywołać chociażby problemy przy częściowym i jednoczesnym spełnianiu poszczególnych celów. Można by zatem rozważyć posłużenie się określeniem nieostrym wskazującym na jeden cel działania podmiotu, natomiast w praktyce podatkowej, szczególnie w orzecznictwie sądów administracyjnych, można byłoby precyzować konkretne działania podatników w tym celu, a nawet wskazywać cele cząstkowe i przyporządkowane im działania.

19 A zatem przepis art. 22 ust. 1 u.p.d.f., pełniący rolę definicji kosztów uzyskania przychodów, oraz art. 23, gdzie wskazuje normodawca wydatki nieuznawane za koszty uzyskania przychodów.

${ }^{20}$ Chodzi o działanie w celu osiągnięcia przychodów lub zachowania albo zabezpieczenia źródła przychodów. 


\section{Podsumowanie}

Rozpatrywanie określeń nieostrych w ramach elementu konstrukcji prawnej podatku, tj. przedmiotu opodatkowania, jest jednym z kluczowych zagadnień dla szczegółowego prawa podatkowego. Chodzi bowiem o wyrażenie zakresu opodatkowania z możliwym wykorzystaniem środków techniki prawodawczej zapewniających elastyczność przepisów prawa podatkowego. Nie chodzi tu o postulowanie szerszego wykorzystania tych środków techniki prawodawczej, gdyż stoi to w pewnej sprzeczności z administracyjnoprawną metodą regulacji. Akcent należy bowiem postawić na sposób użycia tych środków legislacyjnych. Istotnego znaczenia nabiera więc dopasowanie omawianych tu rozwiązań do specyfiki konstrukcji przedmiotu opodatkowania w danym rodzaju podatku.

Dokonana w niniejszym opracowaniu analiza przepisów tworzących pewne zręby przedmiotu opodatkowania w podatku dochodowym od osób fizycznych nie pozwala na wyciągnięcie wniosków pozytywnych dla ustawodawcy podatkowego. Warto bowiem postulować rozważenie pewnego doprecyzowania określenia nieostrego wskazującego na inne źródła przychodów, gdyż regulacja art. 20 u.p.d.f. nie spełnia tej roli. Być może dobrym rozwiązaniem byłoby wprowadzenie pewnych kryteriów pozwalających ustalić tzw. inne źródła przychodów. Obecny stan powoduje bowiem zbyt duży obszar nieostrości.

Również w odniesieniu do regulacji definicji kosztów uzyskania przychodów warto rozważyć ograniczenie wyrażeń będących określeniami nieostrymi, gdyż powoduje to trudności w ustaleniu tzw. rzeczywistego celu działania podatnika. Można więc postulować wskazanie jednego celu działania podatnika, natomiast jego doprecyzowanie pozostawić orzecznictwu sądów administracyjnych. Ponadto sam przepis art. 22 u.p.d.f. traci na walorze definicyjnym $\mathrm{z}$ uwagi na tak szerokie posłużenie się określeniami nieostrymi.

\section{Bibliografia}

Choduń A., Gomułowicz A., Skoczylas A., Klauzule generalne i zwroty niedookreślone $w$ prawie podatkowym i administracyjnym. Wybrane zagadnienia teoretyczne i orzecznicze, Wolters Kluwer Polska, Warszawa 2013.

Borszowski P., Określenia nieostre i klauzule generalne w prawie podatkowym, Wolters Kluwer Polska, Warszawa 2017.

Mastalski R., Prawo podatkowe, C.H. Beck, Warszawa 2016.

Mastalski R., Fojcik-Mastalska E., Zasada zupełności ustawowej w prawie podatkowym [w:] Konstytucja: ustrój, system finansowy państwa. Ksiegga pamiątkowa ku czci prof. Natalii Gajl, red. T. Dębowska-Romanowska, A. Jankiewicz, Warszawa 1999.

Münnich M., Nieostre zwroty ocenne $w$ polskim prawie podatkowym, Wydawnictwo KUL, Lublin 2017.

Zieliński M. [w:] S. Wronkowska, M. Zieliński, Komentarz do zasad techniki prawodawczej, Wydawnictwo Sejmowe, Warszawa 2012. 